\title{
SWAT model calibration of a grid-based setup
}

\author{
H. Rathjens and N. Oppelt \\ Kiel University, Department of Geography, Ludewig-Meyn-Str. 14, 24098 Kiel, Germany \\ Correspondence to: H. Rathjens (rathjens@geographie.uni-kiel.de)
}

Received: 31 January 2012 - Revised: 12 June 2012 - Accepted: 4 November 2012 - Published: 11 December 2012

\begin{abstract}
The eco-hydrological model SWAT (Soil and Water Assessment Tool) is a useful tool to simulate the effects of catchment processes and water management practices on the water cycle. For each catchment some model parameters (e.g. ground water delay time, ground water level) remain constant and therefore are used as constant values; other parameters such as soil types or land use are spatially variable and thus have to be spatially discretized. SWAT setup interfaces process input data to fit the data format requirements and to discretize the spatial characteristics of the catchment area. The primarily used configuration is the sub-watershed discretization scheme. This spatial setup method, however, results in a loss of spatial information which can be problematic for SWAT applications that require a spatially detailed description of the catchment area. At present no SWAT interface is available which provides the management of input and output data based on grid cells. To fill this gap, the authors developed a grid-based model interface.

To perform hydrological studies, the SWAT user first calibrates the model to fit to the environmental and hydrological conditions of the catchment. Compared to the sub-watershed approach, the grid-based setup significantly increases model computation time and hence aggravates calibration according to established calibration guidelines. This paper describes how a conventional set of sub-watershed SWAT parameters can be used to calibrate the corresponding grid-based model. The procedure was evaluated in a sub-catchment of the River Elbe (Northern Germany). The simulation of daily discharge resulted in Nash-Sutcliffe efficiencies ranging from 0.76 to 0.78 and from 0.61 to 0.65 for the calibration and validation period respectively; thus model performance is satisfactory. The sub-watershed and grid configuration simulate comparable discharges at the catchment outlet $\left(R^{2}=0.99\right)$. Nevertheless, the major advantage of the grid-based set-up is an enhanced spatial description of landscape units inducing a more realistic spatial distribution of model output parameters.
\end{abstract}

\section{Introduction}

The eco-hydrological model SWAT (Soil and Water Assessment Tool, Arnold et al., 1998) is a useful tool for a wide range of scales and environmental conditions. In literature manifold SWAT applications have been reported; the topics cover hydrological and water resource assessments (water discharge, groundwater dynamics, soil water, snow dynamics, water management), water quality assessments (land-use and land-management change in agriculture), climate change impacts, and pollutant assessments (Gassman et al., 2007); a detailed review can be found in Gassman et al. (2007) and Krysanova and Arnold (2008).

To set up a SWAT model run, the watershed has to be delineated and the spatial arrangement of catchment elements (e.g. sub-catchments, reach segments and point sources) has to be defined (Neitsch et al., 2011a). The most popular setup is the sub-watershed configuration, where the catchment is divided into sub-catchments and further sub-divided into hydrologic response units (HRUs). The HRUs represent percentages of the sub-catchment area (Gassman et al., 2007). Individual areas of similar soil, topography and landuse are lumped together within a sub-catchment to form an HRU while in reality they are scattered throughout the subcatchment. Thus this approach fails to show the interaction between the HRUs as they are spatially unlinked but routed to the outlet of the sub-catchment separately (Arnold et al., 2010).

The grid-based setup within SWAT overcomes the difficulties of the sub-watershed configuration (Rathjens and Oppelt, 2012). The user is able both to refine the spatial resolution of a SWAT model and to obtain spatially distributed model output data. Various GIS (Geographic Information System) applications can process the grid-based output; now the model output of every grid cell with its defined geographical position can be analysed. Due to the open-source status of the SWAT code the grid-based approach will continue 
to evolve as users determine needed improvements, which is an advantage in comparison to other catchment scale rasterbased models such as MIKE-SHE (Refsgaard and Storm, 1995), TOPMODEL (Beven and Kirkby, 1979) or WASIM (Schulla, 1997). The grid based approach, however, significantly increases computation time. Arnold et al. (2010) stated that, applying a one-hectare grid cell size (approx. 50000000 grid cells) to the the Upper Mississippi River basin, the simulation of a single year would require about 13 computation days on a $2.6 \mathrm{GHz}$ processor.

After processing of the input data, model calibration is performed, i.e. model output and in-situ data are compared to improve model input parameters iteratively. According to Neitsch et al. (2011a) the calibration of stream flow is performed in two consecutive steps. The model is calibrated for average annual conditions first; then the user shifts to monthly or daily records to fine-tune the calibration. To obtain sufficient calibration results several model runs might be performed. Model validation follows calibration; the input parameters, which were derived during calibration, now are used to test the resulting model performance for a series of subsequent years (Moriasi et al., 2007). Most applications use the discharge at the catchment outlet to calibrate and validate model performance.

For the grid-based model setup, however, this timeconsuming procedure is impractical. Therefore, this paper provides a method for grid-based SWAT setups to calibrate daily discharge at the catchment outlet. To perform this analysis, calibration parameters are derived with a sub-watershed configuration and then transferred to a grid-based model. The GIS interface ArcSWAT (Winchell et al., 2010) is used to generate the input files for the conventional sub-watershed setup; SWATgrid (Rathjens and Oppelt, 2012) is used to setup the grid cell model. A sub-catchment of the River Elbe, the Bünzau catchment, serves as test site to present and validate the proposed methodology.

\section{Materials and methods}

\subsection{Study area}

The Bünzau catchment is located in the Northern German lowlands (see Fig. 1); it covers an area of $210 \mathrm{~km}^{2}$ and is characterized by flat topography and shallow groundwater levels. The mean annual precipitation is $857 \mathrm{~mm}$ and the mean annual temperature is $9.51{ }^{\circ} \mathrm{C}$ (stations Neumünster and Padenstedt, 2000-2009) (DWD, 2011). The Rivers Buckener Au and Fuhlenau merge north of Aukrug-Innien and form the origin of the River Bünzau; the Rivers Höllenau and Bredenbek form two downstream tributaries. Several drainage pipes and ditches also flow into the Bünzau, which flows in southern direction for $16 \mathrm{~km}$ before it flows into the Stör River. The gauge Sarlhusen is located close to the

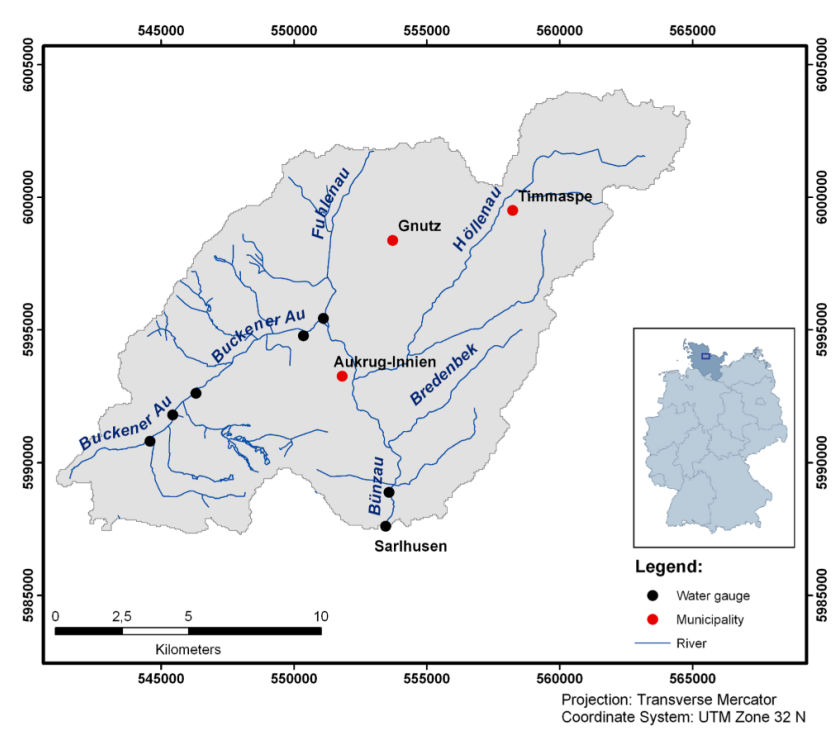

Fig. 1. The Bünzau catchment and its location in Germany.

catchment outlet, where an average discharge of $2.51 \mathrm{~m}^{3} \mathrm{~s}^{-1}$ was measured between 2000 and 2009.

In the Bünzau catchment dominant soils types are podzols and planosols; histosols are found in river valleys and depressions. High proportions of arable land (43\%) and pasture $(30 \%)$ indicate an intense agricultural use; Fig. 2 shows the land use in 2009 as well as the distribution of soil types.

\subsection{The SWAT model}

SWAT (Arnold et al., 1998) is a physically based catchmentscale model; it was developed to simulate the water cycle, the corresponding fluxes of energy and matter (e.g. sediment, nutrients, pesticides and bacteria) as well as the impact of management practices on these fluxes. The design of the model is modular and includes components for hydrology, weather, sedimentation, crop growth, nutrients and agricultural management. A detailed description of all components can be found in Arnold et al. (1998) and Neitsch et al. (2011b).

The simulated hydrological processes include surface runoff (SCS (Soil Conservation Services) curve number or Green and Ampt infiltration equation), percolation, lateral flow, groundwater flow from shallow aquifers to streams, evapotranspiration (Hargreaves, Priestley-Taylor or PenmanMonteith method), snowmelt, transmission losses from streams and water storage and losses from ponds (Arnold et al., 1998).

In this study the SCS curve number method (Soil Conservation Service Engineering Division, 1972) was used to calculate surface runoff; Penman-Monteith method was applied to estimate potential evapotranspiration. 


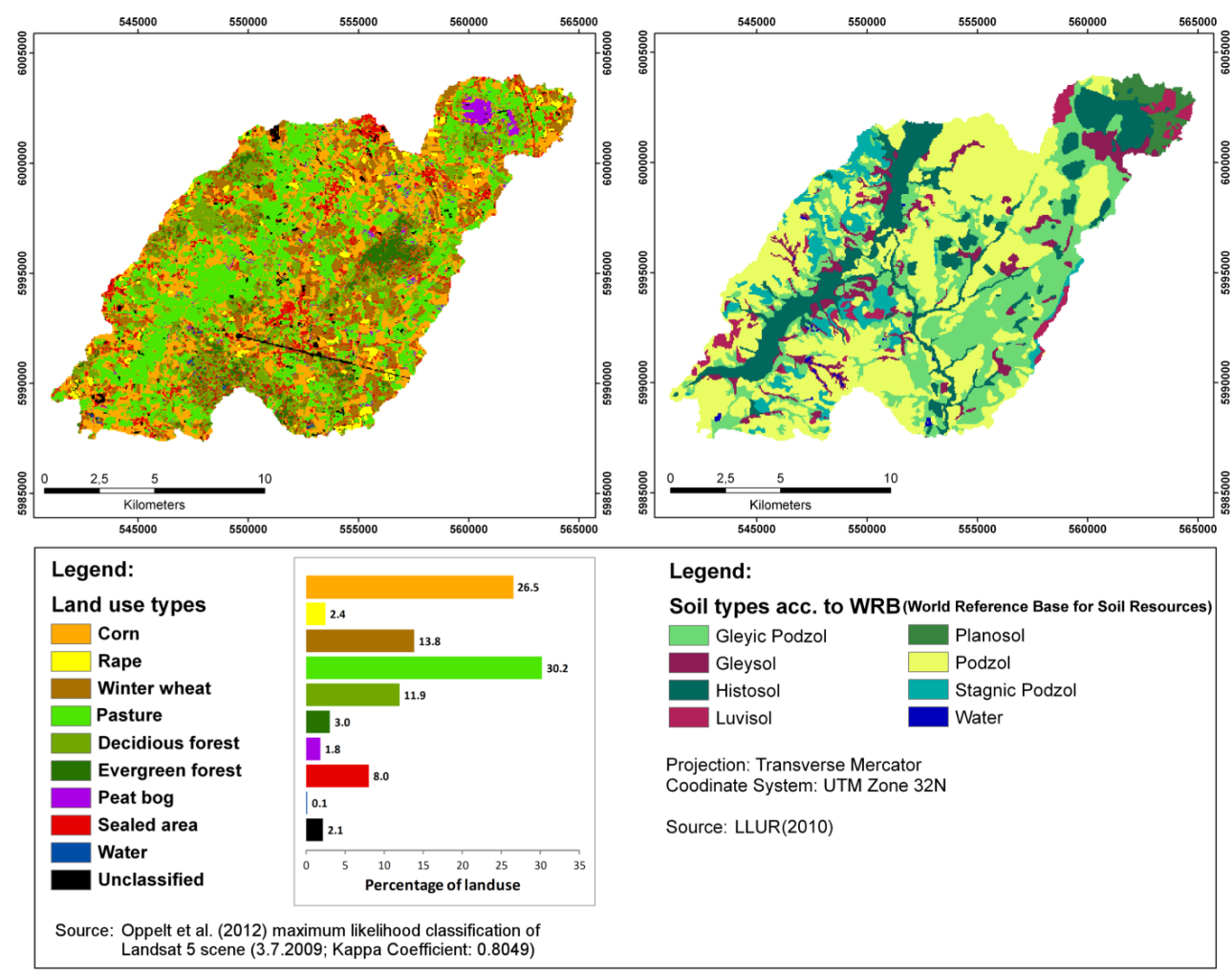

Fig. 2. Land use and soil types in the Bünzau catchment.

\subsection{Model evaluation}

To evaluate model performance four quantitative statistics were applied, i.e. the root mean square error observations standard deviation ratio (RSR; Moriasi et al., 2007), coefficient of determination $\left(R^{2}\right)$, Nash-Sutcliffe efficiency (NSE; Nash and Sutcliffe, 1970) and percent bias (PBIAS; Gupta et al., 1999).

Most simulation studies use different model evaluation techniques to compare simulated output and in-situ measurements (Moriasi et al., 2007). Thus, no comprehensive standardization is available for model evaluation. Moriasi et al. (2007) presented several model evaluation statistics and a step-by-step guideline for model calibration and evaluation. They also reviewed value ranges of evaluation statistics and corresponding performance ratings. They concluded that model simulation for discharge is satisfactory if NSE $>0.50$ (see also Santhi et al., 2001) and RSR $<0.70$ (see also Singh et al., 2004) and $-25 \%<$ PBIAS $<25 \%$.

The RSR standardizes root mean square error (RMSE) values using the standard deviation of in-situ data and thus enables a comparison of error values of different studies. RSR values can range from 0 to $+\infty$; $R S R=0$ indicates that RMSE $=0$ or that the model simulation fits perfectly to the measured data. Large positive RSR values indicate a poor model performance (Moriasi et al., 2007).
The coefficient of determination determines which proportion of in-situ variance can be explained by the model. The values range from $0<R^{2}<1$ where higher values indicate less error variance.

The NSE is a normalized statistical index, which is often used to assess the quality of hydrological models. It determines the relative magnitude of the residual variance between simulated and measured data compared to the in-situ data variance. NSE ranges from $-\infty$ to 1 . An NSE of 1.0 corresponds to a perfect match of modeled and observed data (Moriasi et al., 2007).

PBIAS indicates whether the modelled data tend to be larger or smaller than the corresponding in-situ values. The optimum value is PBIAS $=0.0 \%$; positive PBIAS values indicate a model bias underestimation, whereas negative values indicate a bias overestimation (Gupta et al., 1999).

\subsection{Model input data}

To setup a SWAT model, the essential input data are a digital elevation model (DEM), soil types, land use and climate (see also Table 1). For this study all data were transformed from Universal Transverse Mercator (UTM) to the Albers Equal Area projection.

The DEM is provided by the Land Survey Office Schleswig-Holstein with a vertical resolution of $0.5 \mathrm{~m}$ and a horizontal resolution of $5 \mathrm{~m}$ (LVermA, 2008). 
Table 1. Model input data sources.

\begin{tabular}{|c|c|c|}
\hline Data type & Source & Data description and properties \\
\hline Topography (DEM) & LVermA (2008) & Digital elevation model, $5 \mathrm{~m} \times 5 \mathrm{~m}$ resolution \\
\hline \multirow[t]{2}{*}{ Soil map } & Finnern (1997) & Physical properties of the soil (e.g. available water capacity), scale $1: 100000$ \\
\hline & LLUR (2010) & Physical properties of the soil (e.g. available water capacity), scale $1: 25000$ \\
\hline Land use map 2009 & Oppelt et al. (2012) & Classifications based on Landsat 5 imagery ( 3 July 2009 ), $30 \mathrm{~m} \times 30 \mathrm{~m}$ resolution \\
\hline Climate data & DWD (2011) & $\begin{array}{l}\text { Daily measured values of temperature, precipitation, wind speed, relative humidity } \\
\text { (Neumünster station 2000-2007, Padenstedt station 2007-2009) }\end{array}$ \\
\hline & & Daily measured values of precipitation (Gnutz station 2000-2006) \\
\hline Discharge & LKN (2011) & Daily discharge data of the Bünzau river at gauge Sarlhusen (2000-2009) \\
\hline
\end{tabular}

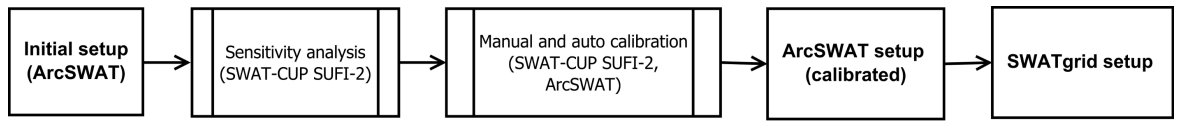

Fig. 3. Grid-based model calibration in chronological order.

The land use map (see Fig. 2) is based on a classification of Landsat 5 imagery from 3 July 2009 (overall-accuracy: $83 \%$, Cohen's kappa coefficient (Cohen, 1960): 0.80). Land use classifications for the years 2009, 2010 and 2011 are used to derive crop rotations planted by the local farmers. Based on these results, SWAT management practices were set as threeyear crop rotation (wheat - wheat - rapeseed), mono-cultural corn and pasture. Winter wheat and rape were planted at the end of September and harvested at the beginning of August; corn is planted at the end of April and harvested at the end of September.

Daily climate values from 1 January 2000 to 31 December 2009 on temperature, precipitation, wind speed and humidity are integrated in the simulation as a composition of three German Weather Service stations (see Table 1).

\subsection{Model setup}

This section demonstrates both how different discretization schemes affect the simulated water balance and whether subwatershed setups may be used to calibrate grid-based model approaches. Figure 3 shows the methodology, which is explained in the following sub-sections.

\subsubsection{Initial setup (ArcSWAT)}

The ArcSWAT interface was used to carry out the basic model setup: catchment and sub-catchment areas were delineated using the DEM (LVermA, 2008); then the catchment was divided into sub-catchments. ArcSWAT calculated nine sub-catchments for the Bünzau catchment. Based on the formation of unique combinations of slope, land use and soil types, the sub-catchments were further divided into 480 HRUs. Finally, daily climate values (see Table 1) from 2000 to 2009 (DWD, 2011) were included into the setup.

\subsubsection{ArcSWAT setup (calibrated)}

After the initial setup, SWAT-CUP (Abbaspour, 2007) was applied to identify the most sensitive model parameters. Sensitivity analysis was carried out using the optimization algorithm SUFI-2 (Sequential Uncertainty Fitting; Abbaspour, 2007). The results showed a strong influence of groundwater parameters (GWQMN, ALPHA_BF, GW_REVAP, REVAPMN), which confirms observations by Dobslaff (2005) and Schmalz and Fohrer (2009). To perform a manual calibration of the most sensitive parameters established guidelines for SWAT model calibration (Santhi et al., 2001; Moriasi et al., 2007; Neitsch et al., 2011a) were applied. Afterwards a second SWAT-CUP calibration was carried out; calibration parameters include the runoff curve number (CNOP), soil available water capacity (SOL_AWC), soil evaporation compensation factor (ESCO), groundwater parameters (GWQMN, ALPHA_BF, GW_REVAP, REVAPMN) and hydraulic conductivity (CH_K, SOL_K). A detailed description of each parameter is provided by Neitsch et al. (2011a).

\subsubsection{SWATgrid setup}

The calibrated input parameter set was transferred to the grid based setup using the SWATgrid interface (Rathjens and Oppelt, 2012); no further calibration was carried out. Therefore, the model parameter set remained equal except for the discretization scheme.

Using SWATgrid the catchment was discretized into 84273 grid cells with a grid resolution of $50 \mathrm{~m}$ by $50 \mathrm{~m}$. To enable a comparison of setups the SWATgrid setup was applied for the same time period.

The grid-based setup significantly increases the model computation time. While the ArcSWAT setup (480 HRUs) takes $30 \mathrm{~s}$ on a single $2.67 \mathrm{GHz}$ processor, the SWATgrid setup lasts about $12 \mathrm{~h}$ per year of simulation. 
Table 2. Mean annual values of water balance components calculated by the two model setups.

\begin{tabular}{lrrr}
\hline Parameter & $\begin{array}{r}\text { ArcSWAT Setup } \\
{[\mathrm{mm}]}\end{array}$ & $\begin{array}{r}\text { SWATgrid Setup } \\
{[\mathrm{mm}]}\end{array}$ & $\begin{array}{r}\text { Difference } \\
{[\mathrm{mm}]}\end{array}$ \\
\hline Precipitation & 853.80 & 853.80 & 0.00 \\
Surface runoff & 10.35 & 12.54 & 2.19 \\
Lateral runoff & 60.402 & 43.81 & -16.59 \\
Tile runoff & 1.95 & 3.25 & 1.30 \\
Groundwater runoff & 290.47 & 303.48 & 13.01 \\
Total water yield & 362.95 & 362.88 & -0.07 \\
Percolation out of soil & 297.40 & 310.69 & 13.29 \\
Evapotranspiration (ET) & 483.40 & 482.20 & -1.20 \\
Potential (ET) & 628.60 & 627.80 & -1.20 \\
\hline
\end{tabular}

Table 3. Model performance (RSR, $R^{2}$, NSE and PBIAS) for the different setups.

\begin{tabular}{|c|c|c|c|c|c|c|c|c|}
\hline \multirow[t]{2}{*}{ Setup } & \multicolumn{2}{|c|}{ RSR } & \multicolumn{2}{|c|}{$R^{2}$} & \multicolumn{2}{|c|}{ NSE } & \multicolumn{2}{|c|}{ PBIAS [\%] } \\
\hline & Calibration & Validation & Calibration & Validation & Calibration & Validation & Calibration & Validation \\
\hline ArcSWAT & 0.47 & 0.60 & 0.78 & 0.67 & 0.78 & 0.65 & -2.97 & 11.16 \\
\hline SWATgrid & 0.49 & 0.62 & 0.77 & 0.64 & 0.76 & 0.61 & -2.94 & 11.29 \\
\hline
\end{tabular}

\section{Results and discussion}

\subsection{Mean annual water balance}

SWAT calculates annual means for the water balance components (see Table 2); for both setups the resulting values are realistic. Dobslaff (2005) and Schmalz and Fohrer (2009) reported similar values for the study area. The results of both model setups demonstrate that groundwater runoff dominates the water balance, a fact that is caused by the low gradients in the catchment. Table 2 also shows that the results of both setups are comparable.

Regarding total water yield and evapotranspiration the model setups fit very well. Lateral runoff calculated by SWATgrid, however, is $16.59 \mathrm{~mm}$ lower than indicated by ArcSWAT. SWATgrid compensates this effect by higher amounts of groundwater runoff $(13.01 \mathrm{~mm})$, surface runoff $(2.19 \mathrm{~mm})$ and tile runoff $(1.30 \mathrm{~mm})$. The runoff components strongly depend on the hydrological characteristics of soil type, land use and slope for which SWATgrid provides a more detailed distribution. Despite these differences, the two model setups are consistent and confirm previous studies (Dobslaff, 2005; Schmalz and Fohrer, 2009). To summarize both model setups result in a sufficient representation of hydrological processes in the Bünzau catchment.

\subsection{Simulation of daily discharge}

Measures of model performance including RSR, $R^{2}$, NSE and PBIAS values are listed in Table 3 . Figure 4 presents daily discharge values that resulted from the ArcSWAT and SWATgrid setups in comparison to values measured at the

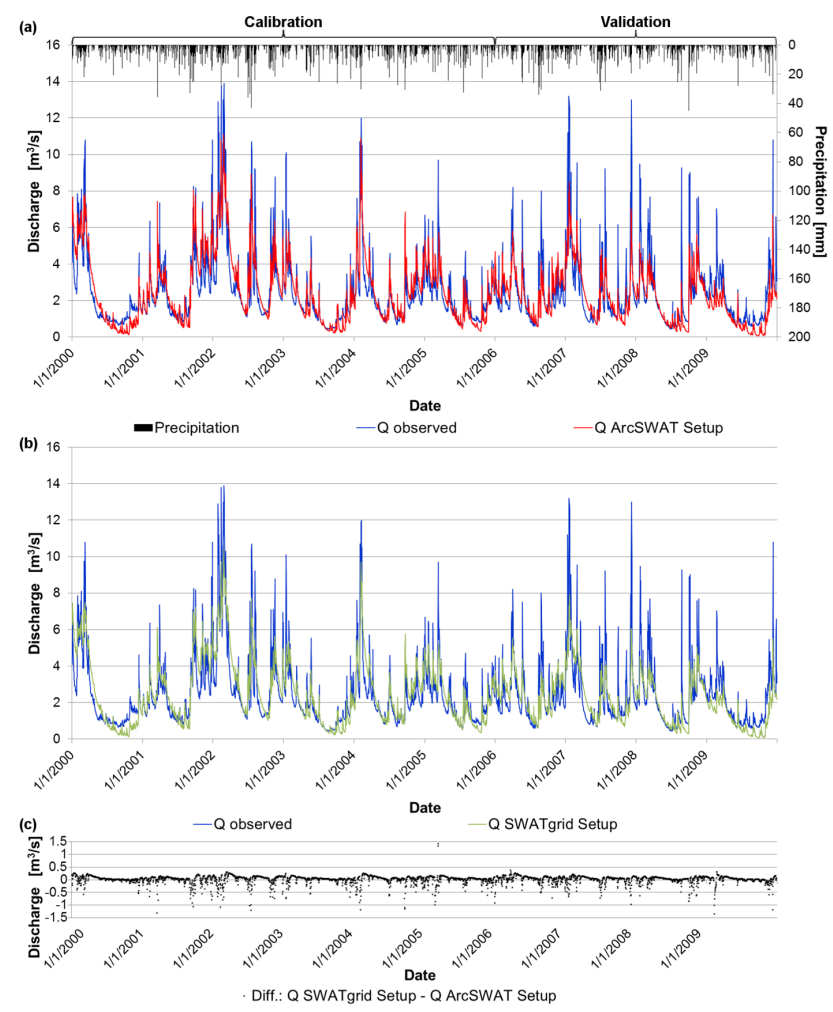

Fig. 4. Measured and simulated daily discharge (calibration period 2000-2005, validation period 2006-2009) at the gauge Sarlhusen (a) ArcSWAT setup, (b) SWATgrid setup, (c) differences of simulated daily discharge (SWATgrid setup - ArcSWAT setup). 
gauge Sarlhusen. Overall comparison of daily discharge simulation values (2000-2009) resulted in a high coefficient of determination $\left(R^{2}=0.99\right)$.

The model evaluation indices RSR, $R^{2}$ and NSE demonstrate that simulated and measured daily discharge agree well for both the calibration and the validation period. The indices also indicate that the ArcSWAT setup performs slightly better that the SWATgrid setup. This might be explained by two facts: (1) values of summer and winter peak flows are higher in ArcSWAT; (2) ArcSWAT shows a faster and more realistic recession of discharge (see also Fig. 4). The different proportions of fast and slow runoff components (see also Sect. 3.1), i.e. surface, lateral and groundwater runoff are generated at HRU or grid-cell level. Thus, modifications that affect the distribution and composition of land use, soil types and slope do have an impact on modelled streamflow components.

Values of PBIAS of the different model setups range from -3 to $11 \%$. The PBIAS differences between the setups are less than 0.2 percentage points; the low number indicates that the modelled discharge is insensitive to changing discretization schemes. Drainage density (total channel length divided by drainage area) increases as the number of grid cells or sub-catchments increases. As a result transmission and deep aquifer losses increase and reduce discharge. Thus, these losses cause the lower runoff calculated by the SWATgrid setup compared to the ArcSWAT setup (see Table 3). Nevertheless, the differences are relatively small compared to the differences of discharge components caused by the kind of discretization. Similar observations were made by Bingner et al. (1997), FitzHugh and Mackay (2000), Chen and Mackay (2004), Jha et al. (2004), Haverkamp et al. (2005), Arabi et al. (2006) and Cho et al. (2010).

In summary, model performance statistics shows that simulated and observed daily discharge is similar for both the calibration and the validation period. The grid-based model calculates daily discharge at the catchment outlet according to the sub-watershed model. The calibration of the grid-based model using the sub-watershed parameter set resulted in a satisfactory model performance. Statistical indices (RSR, $R^{2}$, NSE and PBIAS) confirm this finding.

\section{Conclusions}

The grid-based discretization scheme (SWATgrid) incorporates spatially distributed data into a SWAT model run and enables detailed analysis of every output grid cell at its geographical position. The grid-based setup significantly increases the model computation time. While the conventional ArcSWAT model run takes $30 \mathrm{~s}$ on a single $2.67 \mathrm{GHz}$ processor, the SWATgrid setup lasts about $12 \mathrm{~h}$ per year of simulation; therefore calibration using existing guidelines is impractical.

A time efficient procedure to calibrate grid-based setups was evaluated in a lowland catchment in Northern Germany.
An ArcSWAT interface was applied to provide an initial, uncalibrated sub-watershed setup. Afterwards, the most sensitive parameters to water balance were obtained using SWATCUP. The sub-watershed setup then was calibrated with established manual and automatic calibration techniques. The resulting parameter set was transferred to a grid-based setup using the SWATgrid interface.

The Bünzau catchment, a sub-watershed of the River Elbe, served as a test site to evaluate the proposed methodology. Model performance according to (Moriasi et al., 2007) was derived using statistical indices (RSR, $R^{2}$, NSE and PBIAS). All indices showed a satisfactory model performance.

Daily discharge derived from the grid configuration matched well with the sub-watershed discharge (ArcSWAT setup) at the catchment outlet $\left(R^{2}=0.99\right)$. Thus, established sub-watershed calibration techniques (Santhi et al., 2001; Moriasi et al., 2007; Neitsch et al., 2011b) can be used to obtain a parameter set for a grid-based SWAT setup. The results presented, however, are limited to the study area; further studies could compare this calibration method with a "real" grid-based model calibration to confirm these findings.

Acknowledgements. The authors would like to thank the Department of Hydrology and Water Resources Management (Kiel University) and the Schleswig-Holstein state offices LLUR, LKN and LVA for providing the data sets. We also express our gratitude for the efforts of the reviewers.

Edited by: K. Schneider and S. Achleitner

Reviewed by: two anonymous referees

\section{References}

Abbaspour, K. C.: User Manual for SWAT-CUP, SWAT Calibration and Uncertainty Analysis Programs, Swiss Federal Institute of Aquatic Science and Technology, EAWAG, Dübendorf, Switzerland, 2007.

Arabi, M., Govindaraju, R. S., Hantush, M. M., and Engel, B. A.: Role of watershed subdivision on modeling the effectiveness of best management practices with SWAT, J. Am. Water Resour. As., 42, 513-528, 2006.

Arnold, J. G., Srinivasan, R., Muttiah, R. S., and Williams, J. R.: Large area hydrologic modeling and assessment part I: model development, J. Am. Water Resour. As., 34, 73-89, 1998.

Arnold, J., Allen, P., Volk, M., Williams, J., and Bosch, D.: Assessment of different representations of spatial variability on SWAT model performance, T. ASABE, 53, 1433-1443, 2010.

Beven, K. J. and Kirkby, M. J.: A physically based, variable contributing area model of basin hydrology, Hydrolog. Sci. Bull., 24, 43-69, 1979.

Bingner, R., Garbrecht, J., Arnold, J., and Srinivasan, R.: Effect of Watershed Subdivision on Simulation Runoff and Fine Sediment Yield, Transactions of the American Society of Agricultural Engineers, 40, 1329-1335, 1997. 
Chen, E. and Mackay, D. S.: Effects of distribution-based parameter aggregation on a spatially distributed agricultural nonpoint source pollution model, J. Hydrol., 295, 211-224, 2004.

Cho, J., Lowrance, R. R., Bosch, D. D., Strickland, T. C., Her, Y., and Vellidis, G.: Effect of Watershed Subdivision and Filter Width on SWAT Simulation of a Coastal Plain Watershed, J. Am. Water Resour. As., 46, 586-602, 2010.

Cohen, J.: A Coefficient of Agreement for Nominal Scales, Educ. Psychol. Meas., 20, 37-46, 1960.

Dobslaff, N.: GIS-basierte Modellierung von Wasserhaushalt und Abflussbildung am Beispiel des Einzugsgebietes der oberen Stör, Diploma thesis, Department of Hydrology and Water Resources Management, Kiel University, 2005.

DWD: Weather and Climate Data from the German Weather Service - Station Gnutz (1997-2006), Neumünster (1997-2007) and Padenstedt (2007-2010), Deutscher Wetterdienst, 2011.

Finnern, J.: Böden und Leitbodengesellschaften des Störeinzugsgebietes in Schleswig-Holstein - Vergesellschaftung und Stoffaustragsprognose ( $\mathrm{K}, \mathrm{Ca}, \mathrm{Mg}$ ) mittels GIS, Dissertation, Institut für Pflanzenernährung und Bodenkunde, Kiel University, 1997.

FitzHugh, T. W. and Mackay, D. S.: Impacts of input parameter spatial aggregation on an agricultural nonpoint source pollution model, J. Hydrol., 236, 35-53, 2000.

Gassman, P. W., Reyes, M. R., Green, C. H., and Arnold, J. G.: The Soil and Water Assessment Tool: historical development, applications, and future research directions, T. ASABE, 50, 12111250, 2007.

Gupta, H. V., Sorooshian, S., and Yapo, P. O.: Status of Automatic Calibration for Hydrologic Models: Comparison with Multilevel Expert Calibration, J. Hydrol. Eng., 4, 135-143, 1999.

Haverkamp, S., Fohrer, N., and Frede, H.-G.: Assessment of the effect of land use patterns on hydrologic landscape functions: a comprehensive GIS-based tool to minimize model uncertainty resulting from spatial aggregation, Hydrol. Process., 19, 715$727,2005$.

Jha, M., Gassman, P., Secchi, S., Gu, R., and Arnold, J.: Effect of watershed subdivision on SWAT flow, sediment, and nutrient predictions, J. Am. Water Resour. As., 40, 811-825, 2004.

Krysanova, V. and Arnold, J. G.: Advances in ecohydrological modelling with SWAT-a review, Hydrolog. Sci. J., 53, 939-947, 2008.

LKN: Daily Discharge Data from the State Office for Coastal Protection, National Park and Marine Protection - Gauging Station Sarlhusen (Number 114131), Landesbetrieb für Küstenschutz, Nationalpark und Meeresschutz Schleswig-Holstein, 2011.

LLUR: Soil Map $(1: 25.000)$ of Schleswig-Holstein from the Agency for Nature and Environment Schleswig-Holstein, Landesamt für Landwirtschaft, Umwelt und ländliche Räume des Landes Schleswig-Holstein, 2010.

LVermA: ATKIS-DEM $5 \mathrm{~m}$ grid size Derived from LiDAR Data, Land Survey Office Schleswig-Holstein, Landesamt für Vermessung und Geoinformation Schleswig-Holstein, 2008.
Moriasi, D. N., Arnold, J. G., Liew, M. W. V., Bingner, R. L., Harmel, R. D., and Veith, T. L.: Model Evaluation Guidelines for Systematic Quantification of Accuracy in Watershed Simulations, T. ASABE, 50, 885-900, 2007.

Nash, J. and Sutcliffe, J.: River flow forecasting through conceptual models part 1 - A discussion of principles, J. Hydrol., 10, 282290, 1970.

Neitsch, S. L., Arnold, J. G., Kiniry, J. R., Srinivasan, R., and Williams, J. R.: Soil and Water Assessment Tool Input/Output File Documentation: Version 2009, Texas Water Ressources Institute Technical Report 365, Texas A\&M University System, College Station (Texas), 2011a.

Neitsch, S. L., Arnold, J. G., Kiniry, J. R., and Williams, J. R.: Soil and Water Assessment Tool Theoretical Documentation Version 2009, Texas Water Ressources Institute Technical Report 406, Texas A\&M University System, College Station (Texas), $2011 \mathrm{~b}$.

Oppelt, N., Rathjens, H., and Dörnhöfer, K.: Integration of land cover data into the open source model SWAT, in: Proceedings of the First Sentinel-2 Preparatory Symposium held on 2327 April 2012 in ESA-ESRIN, Frascati, Italy, SP707, DVD Publication, 2012.

Rathjens, H. and Oppelt, N.: SWATgrid: An interface for setting up SWAT in a grid-based discretization scheme, Comput. Geosci., Comput. Geosci., 45, 161-167, 2012.

Refsgaard, J. and Storm, B.: Computer Models of Watershed Hydrology, chap. MIKE SHE, 809-846, Water Resources Publications, Colorado, USA, 1995.

Santhi, C., Arnold, J. G., Williams, J. R., Dugas, W. A., Srinivasan, R., and Hauck, L. M.: Validation of the swat model on a large river basin with point and nonpoint sources, J. Am. Water Resour. As., 37, 1169-1188, 2001.

Schmalz, B. and Fohrer, N.: Comparing model sensitivities of different landscapes using the ecohydrological SWAT model, Adv. Geosci., 21, 91-98, doi:10.5194/adgeo-21-91-2009, 2009.

Schulla, J.: Hydrologische Modellierung von Flussgebieten zur Abschätzung der Folgen von Klimaänderungen, Ph.D. thesis, Geographisches Institut, ETH Zürich, 1997.

Singh, J., Knapp, H. V., and Demissie, M.: Hydrologic Modeling of the Iroquois River Watershed Using HSPF and SWAT, Illinois State Water Survey Contract Report 2004-08, Illinois Department of Natural Resources and Illinois State Geological Survey, 2004.

Soil Conservation Service Engineering Division: Section 4: Hydrology, in: National Engineering Handbook, 1972.

Winchell, M., Srinivasan, R., Di Luzio, M., and Arnold, J. G.: ArcSWAT Interface For SWAT 2009: User's Guide, Texas Agricultural Experiment Station (Texas) and USDA Agricultural Research Service (Texas), Temple (Texas), 2010. 